\title{
Methemoglobinemia incidence after the application of lidocaine for small surgical procedures
}

\author{
Küçük cerrahi işlemlerde lidokain uygulaması sonrası methemoglobinemi insidansı
}

\author{
Elnare GÜNAL, ${ }^{1}$ Yeliz AKKUŞ, ${ }^{2}$ Gülşen ÇıĞŞAR, ${ }^{1}$ Handan ÇifTÇi, ${ }^{1}$ Şahin KAHRAMANCA, ${ }^{3}$ Murat ÖZDEMIR'
}

\begin{abstract}
Summary
Objectives: Methemoglobinemia (MetHb) is a rare condition that may have mortal consequences. Literature shows cases of methemoglobinemia due to the use of lidocaine and other local anesthetics. This is a cross-sectional study to determine the incidence of methemoglobinemia after the application of lidocaine.

Methods: In this study, 88 patients admitted to the emergency department of a university hospital between May 2014 and May 2015 and needed lidocaine application for small surgical procedures were included. When compared before and after the administration of lidocaine $<2 \mathrm{mg} / \mathrm{kg}$ and $>2 \mathrm{mg} / \mathrm{kg}$, there was not a significant difference in the level of methemoglobin, hemoglobin, or in the hematocrit ( $p=0.604, p=0.502$, and $p=0.367$, respectively).

Results: Mean age of the patients was $33.85( \pm 17.58)$ years, and $83 \%$ of the patients were male. Methemoglobin levels were not significantly different before and after the procedures $(p>0.05)$.

Conclusion: The results of our study were consistent with the literature; lidocaine-associated methemoglobinemia is a rare complication.
\end{abstract}

Keywords: Local lidocaine application; methemoglobinemia; small surgical procedures.

\begin{abstract}
Özet
Amaç: Methemoglobulinemi nadir görülen ancak ölümcül sonuçları olan acil bir durumdur. Literatürde lokal anestezikler ve bunlar içinde yer alan lidokaine bağlı methemoglobinemi oluşumuna ilişkin vakaların olduğu bildirilmiştir. Bu nedenle çalışmamız lidokain kullanılan hastalarda methemoglobulinemi insidansını belirlemek amacıyla kesitsel olarak yapılmışıı.

Gereç ve Yöntem: Bir üniversite hastanesinin acil servisine Mayıs 2014-Mayıs 2015 tarihleri arasında başvuran küçük cerrahi işlem nedeniyle lidokain uygulanması gereken 88 hasta çalışma kapsamına alınmıştır. İşlem öncesi ve sonrası methemoglobulin değerleri ölçülmüştür.

Bulgular: Hastaların yaş ortalaması 33.85 ( \pm 17.58 ) olup hastaların \%83'ü erkekti. İşlem öncesi ve işlem sonrası karşılaştıııdığında lidokainin $2 \mathrm{mg} / \mathrm{kg}$ kullanımına göre methemoglobin, hemoglobin ve hemotokrit değerlerinde anlamlı bir farklılık bulunamadı $(p=0.604, p=0.502$ and $p=0.367)$.
\end{abstract}

Sonuç: Çalışmamızın sonuçları literatürle uyumlu olup lidokaine bağlı methemoglobinemi nadir gelişebilmektedir.

Anahtar sözcükler: Lokal lidokain uygulaması; methemoglobinemia; küçük cerrahi işlem.

\section{Introduction}

Iron in hemoglobin is bivalent under normal conditions $\left(\mathrm{Fe}^{++}\right)$. Methemoglobinemia (MetHb) occurs after the oxidation of hemoglobin iron to ferric $\left(\mathrm{Fe}^{+3}\right)$ form. ${ }^{[1]}$ If methemoglobinemia is severe, the transportation of oxygen and carbon dioxide in blood fails and hypoxia, lactic acidosis, and death may occur. ${ }^{[2]}$ Both hereditary and acquired methemoglobin- emia are possible. Methemoglobinemia can be due to the lack of NADH diaphorase, cytochrome b-5, and glucose-6-P dehydrogenase, which reduce methemoglobin , as well as presence of abnormal hemoglobin. ${ }^{[1]}$ Many substances or drugs, including amino benzenes, benzocaine, dapsone, phenytoin, phenacetin, nitrites, nitrates, chlorates, kinins, nitrobenzene, nitrotoluen, chloroquine, sulphonamides, and local anesthetics such as lidocaine (xylocaine), reportedly

\footnotetext{
'Department of Emergency Medicine, Kafkas University, Faculty of Medicine, Kars, Turkey

${ }^{2}$ Department of Nursing, Kafkas University Health Science Faculty, Kars, Turkey

${ }^{3}$ Department of Surgery, Kars Harakani State Hospital, Kars, Turkey
}

Submitted (Başvuru tarihi) 06.01.2017 Accepted after revision (Düzeltme sonrası kabul tarihi) 30.09.2017 Available online date (Online yayımlanma tarihi) 10.11.2017

Correspondence: Dr. Yeliz Akkuş. Kafkas Üniversitesi, Sağlık Bilimleri Fakültesi, Hemşirelik Bölümü, Kars, Turkey.

Phone: +90 -474- 2251567 e-mail: yelizakkus@gmail.com

(C) 2017 Turkish Society of Algology 
cause acquired methemoglobinemia. ${ }^{[3]}$

Local anesthetics are routinely used before invasive procedures. Lethal methemoglobinemia cases are particularly reported after benzocaine application. ${ }^{[4]}$ Lidocaine is one of the most common local anesthetics because of its short-acting profile. It is an amid type local anesthetic that has side effects, such as dizziness, numbness around the mouth and tongue, ataxia, agitation, convulsions, respiratory depression, coma, and cardiovascular collapse. ${ }^{[5]}$ There are case reports of methemoglobinemia due to lidocaine in infants and adults in the literature, although they are rare. ${ }^{[6,7]}$ Therefore, we performed a cross-sectional study to determine the incidence of methemoglobinemia after the application of lidocaine for small surgical procedures in an emergency department.

\section{Materials and Methods}

In this study, we included the patients that were admitted to the emergency department between May 2014 and May 2015 who received Jetokain Ampoule ${ }^{\circledR}$ for small surgical procedures after trauma. Jetokain Ampoule ${ }^{\circledast}$ includes lidocaine hydrochloride $(20 \mathrm{mg} / \mathrm{dl})$ and epinephrine base $(0.0125 \mathrm{mg} / \mathrm{ml})$. There were no age limitations in this cross-sectional study, and all patients who received Jetokain Ampoule ${ }^{\circledR}$ were included. Ethics Committee approval (KAl-58-14.05.2015) was obtained. In addition, informed consent was obtained from patients participating in the study. In total, 124 patients who underwent small surgical procedures were included. Those who did not want to participate in the study were excluded. In addition, patients who left the emergency department and did not wait for 45 minutes after their surgical procedure for a second blood gas test were excluded.

Data were collected with a data collection form. The demographic characteristics of the patients were noted in the first part of the form. The type of the procedure, the dose of applied lidocaine, and patients' MetHb values before and after the application were noted in the second part of the form. In addition, hemoglobin and hematocrit values of the patients were noted. The ABL90 FLEX blood gas evaluation device was used for the assessment in hospital laboratories. No medication was administrated during or after these procedures.
The dose of lidocaine was determined according to the size of cut present in patients. Lidocaine was administered by the emergency physician under the skin of the wound edges using an insulin syringe. MetHb values were taken in the blood gas before lidocaine application. Forty-five minutes after lidocaine application, patients were evaluated clinically, and methemoglobin values were taken in the venous blood gas. Weight of the patients was checked using a Jawo PLUS II electronic scale.

\section{Statistical analysis}

The data analysis was performed using the Statistical Package for the Social Sciences for Windows, version 21.0 (SPSS Inc, Chicago, IL, USA). Whether the distributions of continuous variables were normal was determined by Kolmogorov-Smirnov test. Data were shown as mean \pm standard deviation or median (min-max) values, where applicable. The differences between groups were compared by using Student's t or Mann-Whitney U test, as appropriate. Categorical data were analyzed using Pearson's chi-square test, where appropriate. A p value less than 0.05 was considered statistically significant.

\section{Results}

The mean age of the 88 patients was 33.85 years ( \pm 17.58 years); $83 \%$ of the patients were male, $94.3 \%$ did not have any comorbid disease, $4.6 \%$ had coronary artery disease, $1.1 \%$ had chronic renal failure, $19.3 \%$ were smokers, and $5.7 \%$ consumed alcohol. The median lidocaine dosage administered was $40 \mathrm{mg} / \mathrm{dL}$ (range: $20-280 \mathrm{mg} / \mathrm{dL}$ ), and the average weight of the patients was $67.51 \pm 11.52 \mathrm{~kg}$. The median lidocaine dose was $0.73 \mathrm{mg} / \mathrm{kg}$ (range: 0.22 $5.71 \mathrm{mg} / \mathrm{kg}$ ). Overall, $92 \%$ of the patients were given less than $2 \mathrm{mg} / \mathrm{kg}$ of lidocaine.

The median methemoglobin level after lidocaine application was $0.85 \%$ (range: $0.10-7.60 \%$ ). Table 1 indicates that the mean methemoglobin level before

Table 1. Mean values of MetHb levels before and after minor surgical procedures

\begin{tabular}{ccccc}
\hline & $\begin{array}{c}\text { Lidocaine } \\
\text { Before } \\
\text { application }\end{array}$ & $\begin{array}{c}\text { Lidocaine } \\
\text { After } \\
\text { application }\end{array}$ & t & $\mathbf{p}$ \\
\hline MetHb value & $1.67 \pm 1.79$ & $1.73 \pm 1.91$ & -0.65 & 0.5 \\
\hline
\end{tabular}


Table 2. MetHb levels according to the application of lidocaine doses less than $2 \mathrm{mg} / \mathrm{kg}$ or more than $2 \mathrm{mg} / \mathrm{kg}$

\begin{tabular}{lcccc}
\hline MetHb & $\mathbf{n}(\%)$ & $\mathbf{n}(\%)$ & $\mathbf{n}(\%)$ & $\begin{array}{c}\text { Pearson } \\
\text { chi-square }\end{array}$ \\
\hline Low value & $78(96.2)$ & $7(100)$ & $85(96.5)$ & 0.604 \\
High value & $3(3.8)$ & $0(0.00)$ & $3(3.5)$ & $\mathrm{p}=0.77$ \\
Total & $81(92.0)$ & $7(8)$ & $88(100)$ & \\
\hline
\end{tabular}

Table 3. $\mathrm{Hb}$ and $\mathrm{Htc}$ levels according to the application of lidocaine doses less than $2 \mathrm{mg} / \mathrm{kg}$ or more than $2 \mathrm{mg} / \mathrm{kg}$

\begin{tabular}{lllll}
\hline & $<\mathbf{2} \mathbf{~ m g} / \mathbf{k g}$ & $>\mathbf{2 ~} \mathbf{~ g} / \mathbf{k g}$ & $\begin{array}{l}\text { Value Before } \\
\text { procedure }\end{array}$ \\
\hline Mean Hb & $15.35(2.08)$ & $14.92(0.97)$ & $15.31(2.01)$ & Z: $-0.67, \mathrm{p}: 0.50$ \\
Mean Htc & $46.36(6.48)$ & $44.37(3.36)$ & $46.20(6.30)$ & Z: 0.50, p:0.36 \\
\hline Z: Mann-Whitney U test. & & &
\end{tabular}

and after minor surgical procedures. There was no significant difference in the methemoglobin level before and after the procedures.

Table 2 shows the patients' methemoglobin level according to a lidocaine dose of less than $2 \mathrm{mg} / \mathrm{kg}$ or more than $2 \mathrm{mg} / \mathrm{kg}$. Only $3.8 \%$ of the patients who were given less than $2 \mathrm{mg} / \mathrm{kg}$ of lidocaine had a high methemoglobin level. The methemoglobin level based on a dose of lidocaine of less than or more than $2 \mathrm{mg} / \mathrm{kg}$ was statistically insignificant ( $p=0.604$ ).

Table 3 shows the patients' hemoglobin $(\mathrm{Hb})$ and hematocrit $(\mathrm{Htc}$ ) levels according to the application of lidocaine doses less than $2 \mathrm{mg} / \mathrm{kg}$ or more than 2 $\mathrm{mg} / \mathrm{kg}$. $\mathrm{Hb}$ and Htc levels according to the application of lidocaine less than or more than $2 \mathrm{mg} / \mathrm{kg}$ are statistically insignificant ( $p=0.502$ and $p=0.367$ ).

\section{Discussion}

There are reported cases of methemoglobinemia after lidocaine application; however, there is no largescale incidence study about methemoglobinemia after lidocaine application for small surgical procedures. Therefore, we believe that our study makes an important contribution to the literature. ${ }^{[8,9]}$

MetHb diagnosis is based on clinical and laboratory findings. Central or peripheral cyanosis may develop in patients according to oxygen saturation levels. Chocolate colored blood is suggestive of MetHb, but
MetHb may develop in other colors as well. ${ }^{[10]}$ Pulse oximetry cannot diagnose MetHb because it cannot show the level of desaturation. The diagnosis of methemoglobinemia can be made by blood gas analysis and use of co-oximeter to determine the difference between low arterial oxyhemoglobin saturation $\left(\mathrm{SaO}_{2}\right)$ and high pressure of arterial oxygen $\left(\mathrm{SpO}_{2}\right)$. [11] If the difference between $\mathrm{SaO}_{2}-\mathrm{SpO}_{2}$ is more than $5 \%$, the patient has the tendency toward MetHb. ${ }^{[13]}$

Under normal conditions, blood MetHb levels should be less than $1.5 \%{ }^{[7,13]}$ If MetHb values are more than $5 \% \mathrm{~g} / \mathrm{dL}$, cyanosis can be observed. When the MetHb value is greater than $40 \%$, an increase in cyanosis, respiratory distress, dizziness, headache, tachycardia, weakness, nausea, vomiting, lethargy, or syncope may be observed. ${ }^{[13,14]}$ When the MetHb level is more than $60 \%$, likelihood of mortality increases; in more than $70 \%$ cases, it is lethal. ${ }^{[15]}$ Notably, there is no relationship between symptoms and the level of MetHb. ${ }^{[16]}$

According to our study, there is increase in blood MetHb levels after minor surgical procedures rather than before; however, there are no significant clinical changes and lidocaine does not appear to contribute to the development of methemoglobinemia. Lidocaine is primarily used in esophagogastroduodenoscopy and fiberoptic bronchoscopy; methemoglobinemia due to lidocaine application is mostly seen after lower respiratory tract or gastrointestinal tract procedures. ${ }^{[11,16]}$ Methemoglobinemia following these procedures may develop due to absorption from mucous membranes.

Lidocaine is metabolized in the liver by the cytochrome P450 3A4 enzyme. Its 96-minute half-life is the shortest among anesthetic agents. When lidocaine is used alone, the maximum dose is $4-5 \mathrm{mg} /$ $\mathrm{kg}$ or $300 \mathrm{mg} \cdot{ }^{[17]}$ When used in combination with epinephrine, the dose may be up to $7 \mathrm{mg} / \mathrm{kg}$ or $500 \mathrm{mg}$, if tolerated. ${ }^{[17]}$ According to our study, changes in the level of MetHb based on differences in lidocaine doses administered for minor surgical procedures were not statistically significant. Although it is true it might be due to "Jetokain Ampoule ${ }^{\circledast, "}$ which includes epinephrine base. In the literature, lidocaine-related methemoglobinemia cases are rare. In his retrospective study, Guay ${ }^{[10]}$ implied that three patients devel- 
oped lidocaine-related methemoglobinemia with an incidence of $1 \%$. Neuhaeuser et al. ${ }^{[6]}$ stated that $20 \%$ of infants had elevated levels of MetHb after lidocaine administration in pediatric craniofacial surgery. MetHb cases have also been reported due to use of lidocaine in combination with other drugs. ${ }^{[1]]}$ Although it is not evaluated in our study, MetHb also can develop due to ingestion of nitrates in drinking water or food, dehydration, use of various drugs, and cardiac or respiratory system diseases. ${ }^{[18]}$ Therefore, it is important to consider these factors.

Methemoglobinemia is a rare but potentially lethal condition. Clinical signs of MetHb can vary; therefore, personnel working in emergency departments need to have information about circumstances that lead to the development of MetHb and the signs, symptoms, and treatment of the disease. Lidocaine and other anesthetics are often used in emergency departments. Therefore, health staff working in emergency departments need to identify the patients with risk factors and should take a relevant history from new patients.

\section{Conflict-of-interest issues regarding the authorship or article: None declared.}

Peer-rewiew: Externally peer-reviewed.

\section{References}

1. Türkmen E, Kocabay G, Yavuz S, Öztürk S, Vatansever S, Akkaya $V$, et al. A case of Methemoglobinemia induced by the administration of Prilocaine prior to epilation procedure. J Ist Faculty Med 2005;68:19-2.

2. Akıncı E, Yüzbaşıoğlu Y, Aslay $S$, Coşkun F. Incidence of Metoclopramide-induced Methemoglobinemia. Tr J Emerg Med 2011;11(2):49-53. [CrossRef]

3. Wright RO, Lewander WJ, Woolf AD. Methemoglobinemia: etiology, pharmacology, and clinical management. Ann Emerg Med 1999;34(5):646-56. [CrossRef]

4. Vallurupalli S, Manchanda S. Risk of acquired methemoglobinemia with different topical anesthetics during endoscopic procedures. Local Reg Anesth 2011;4:25-8. [CrossRef]

5. Çelik M, Soyuer ÖU, Şekerel BE. Lidocain connected toxi- city or allergy? Astım Allerji İmmünoloji 2008;6(1):22-4.

6. Neuhaeuser C, Weigand N, Schaaf H, Mann V, Christophis $P$, Howaldt HP, et al. Postoperative methemoglobinemia following infiltrative lidocaine administration for combined anesthesia in pediatric craniofacial surgery. Paediatr Anaesth 2008;18(2):125-31.

7. Filipiak-Strzecka D, Kasprzak JD, Wiszniewska M, WalusiakSkorupa J, Lipiec P. The influence of lidocaine topical anesthesia during transesophageal echocardiography on blood methemoglobin level and risk of methemoglobinemia. Int J Cardiovasc Imaging 2015;31(4):727-31. [CrossRef]

8. Bayram M, Özkocaman V, Yeşilbursa D, Özkalemkaş F, Ali R, Irmak G, et al. Methemoglobinemia developing in a patient after administration of lidocaine as topical anesthesia during transesophageal echocardiography. Uludağ University Med Fac J 2011;37(2):99-101.

9. Sarsu SB, Şahin K, Saraç F. A case of methemoglobinemia due to lidocaine prilocaine cream application for burns. Child Surg J 2014;28(2):45-8.

10. Guay J. Methemoglobinemia related to local anesthetics: a summary of 242 episodes. Anesth Analg 2009;108(3):837-45.

11. Kwok S, Fischer JL, Rogers JD. Benzocaine and lidocaine induced methemoglobinemia after bronchoscopy: a case report. J Med Case Rep 2008;2:16. [CrossRef]

12. El-Husseini A, Azarov N. Is threshold for treatment of methemoglobinemia the same for all? A case report and literature review. Am J Emerg Med 2010;28(6):748.e5-748.e10.

13. Barash M, Reich KA, Rademaker D. Lidocaine-induced methemoglobinemia: a clinical reminder. J Am Osteopath Assoc 2015;115(2):94-8. [CrossRef]

14. Gülgün M, Kul M, Sarıcı S. Prilocaine-induced methemoglo- binemia: report of two cases and review of literature. Erciyes Med J 2007;29(4):322-5.

15. Udeh C, Bittikofer J, Sum-Ping ST. Severe methemoglobinemia on reexposure to benzocaine. J Clin Anesth 2001;13(2):128-30. [CrossRef]

16. De S. Assessment of severity of methaemoglobinemia following fibreoptic bronchoscopy with lidocaine. Indian J Chest Dis Allied Sci 2011;53(4):211-4.

17. Cox B, Durieux ME, Marcus MA. Toxicity of local anaesthetics. Best Pract Res Clin Anaesthesiol 2003;17(1):111-36.

18. Fewtrell L. Drinking-water nitrate, methemoglobinemia, and global burden of disease: a discussion. Environ Health Perspect 2004;112(14):1371-4. [CrossRef] 